\title{
Evaluation of The Facility layout on The Fried Onion Production Process
}

\author{
Rachmad Hidayat ${ }^{1}$, Shofi fitrotis Salimah ${ }^{1 *}$, Moh. Jufriyanto ${ }^{2}$, and M.Firman Khaqiqi ${ }^{2}$ \\ ${ }^{1}$ Industrial Department, Engineering Faculty, University of Trunojoyo Madura \\ ${ }^{2}$ Industrial Department, Engineering Faculty, University of Muhammadiyah Gresik
}

\begin{abstract}
Analysis of the design of the facility layout can improve the performance of production lines such as decreasing congestion levels, minimizing material handling costs. PT. XYZ is one of the fried onion companies has constraints on the material handling system that is less efficient because it takes a long time in the process. Therefore, there will be improvements to the layout of PT. XYZ to increase productivity and shorten the time of the production cycle. The method used is From to Chart the method is a conventional technique commonly used for planning factory layouts and moving goods in a production process. From the results obtained that the proposed layout is better than the initial layout with a higher flow efficiency value of $86.18 \%$. The proposed layout utilizes vacant land, so that the production flow does not repeat and does not rotate far, so that the distance between the areas is getting closer.
\end{abstract}

Keywords: Facility layout, Form to chart, Material handling, Backward and Forward analysis.

\section{Introduction}

Optimal facility layout planning is necessary to maximize production capacity and efficiency. [1] Much research has been done to improve the facility's layout system to improve work efficiency. [1]- [23]. Proper analysis of the design of the facility layout can improve the performance of production lines such as decreasing congestion levels, minimizing material handling costs, reducing idle time, improving efficiency and utilization of labour, equipment and space [2]; [24].

Facility layout problems are found in certain types of manufacturing systems that affect the performance of the system of the company. High material handling distance, congestion at work stations, idle time from production and worker facilities, inconvenience and frequent labour accidents are symptoms to need to redesign the layout of the facility [26].

PT. XYZ is one of the fried onion companies has constraints on the material handling system that is less efficient because it takes a long time in the process. A less systematic material handling system becomes a considerable problem and interferes with the smoothness of the production process so that it can affect a system as a whole. Then it is necessary to handle the layout of facilities that can support aspects of smooth flow of materials. [20]. Therefore, in this research will be improved the layout of pt. XYZ to increase productivity and shorten the time of the production cycle.
The method used is From to Chart, a conventional technique commonly used for planning factory layouts and moving goods in a production process.

\section{Methods}

The data used in research is primary data and secondary data. Primary data is the measurement of distance between machines and measurement of weight of fried onion products. Secondary data in the form of layout of fried onion production flow. The picture of the flow layout of the fried onion production process is:

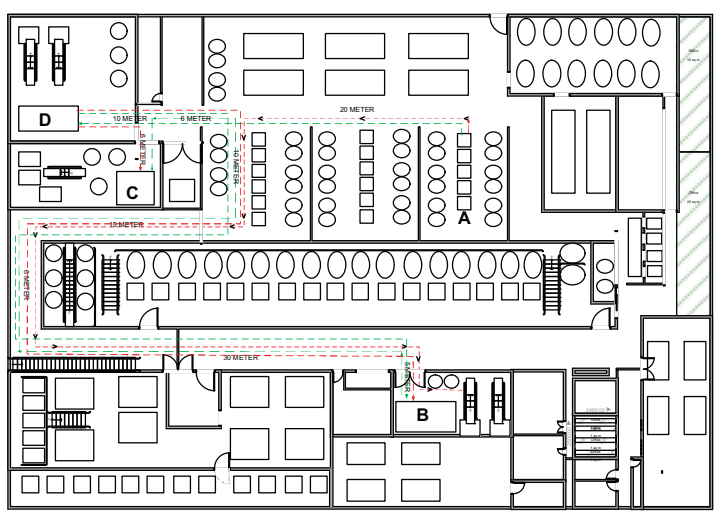

Fig 1. Layout of the flow of the fried onion production process

*Corresponding author : shofi.fitrotis@trunojoyo.ac.id 
From figure 1 of the layout describes the flow of fried onion production starting from the frying area (A), then heading to the cooling area (B), then heading to the area of the flour between the fried onion skin and the meat (D), after that it goes to the smoothing and mixing area, in that area the fried onion will be smoothed and mixed with other products (C). The data supporting the distance and weight of the product that can be moved as follows :

Table 1. Data on production flow, distance, and weight of products

\begin{tabular}{|c|c|c|c|}
\hline From the area & To the area & $\begin{array}{c}\text { Distance } \\
\text { (meter) }\end{array}$ & $\begin{array}{c}\text { Weight } \\
(\mathrm{Kg})\end{array}$ \\
\hline A (frying pan) & B (cooling) & 86 & 192 \\
\hline A (frying pan) & $\begin{array}{c}\text { D (area of } \\
\text { separation of } \\
\text { skin and flesh) }\end{array}$ & 36 & 192 \\
\hline $\begin{array}{c}\text { D (area of } \\
\text { separation of } \\
\text { skin and flesh) }\end{array}$ & B (cooling) & 72 & 191 \\
\hline B (cooling) & $\begin{array}{c}\text { D (area of } \\
\text { separation of } \\
\text { skin and flesh) }\end{array}$ & 72 & 192 \\
\hline B (cooling) & $\begin{array}{c}\text { C (mix area } \\
\text { with other } \\
\text { products) }\end{array}$ & 78 & 191 \\
\hline $\begin{array}{c}\text { D (area of } \\
\text { separation of } \\
\text { skin and flesh) }\end{array}$ & $\begin{array}{c}\text { C (mix area } \\
\text { with other } \\
\text { products) }\end{array}$ & 15 & 191 \\
\hline
\end{tabular}

As for the completion by method From To Chart as follows [25] :

- Identify the production flow of each product

- Identify supporting data such as distance, product weight, production capacity and so on.

- Perform conversion values from supporting data.

- Perform a production travel table analysis

- Perform forward and backward analysis. This analysis aims to determine the efficiency of a trajectory.

Forward flow formula:

$\frac{\text { Total number of flow on the forward }}{\text { total production flow }} \times 100 \%$

Backward flow formula:

$\frac{\text { Total number of flow on the backward }}{\text { tota production flow }} \times 100 \%$ total production flow

- If the efficiency value of the track $>75 \%$ then it can be said to be good.

\section{Results}

\subsection{Initial Layout Analysis}

\subsubsection{Conversion support data and initial layout travel data}

Here's a table of supporting data conversion data and initial layout travel data:

Table 2. Initial layout conversion values

\begin{tabular}{|c|c|c|c|c|}
\hline \multirow{4}{*}{ Product } & Flow & $\begin{array}{c}\text { distance } \\
\text { (Meter) }\end{array}$ & $\begin{array}{c}\text { Weight } \\
(\mathrm{Kg})\end{array}$ & $\begin{array}{c}\text { Conversion } \\
\text { Value }\end{array}$ \\
\hline \multirow{4}{*}{$\begin{array}{c}\text { Fried } \\
\text { Onion }\end{array}$} & $\mathrm{A}->\mathrm{B}$ & 86 & 192 & 16512 \\
\cline { 2 - 5 } & $\mathrm{A}->\mathrm{D}$ & 36 & 192 & 6912 \\
\cline { 2 - 5 } & $\mathrm{D}->\mathrm{B}$ & 72 & 191 & 13752 \\
\cline { 2 - 5 } & $\mathrm{B}->\mathrm{D}$ & 72 & 192 & 13824 \\
\cline { 2 - 5 } & $\mathrm{B}->\mathrm{C}$ & 78 & 191 & 14898 \\
\cline { 2 - 5 } & $\mathrm{D}->\mathrm{C}$ & 15 & 191 & 2865 \\
\hline
\end{tabular}

The conversion value is obtained from the multiplication between distance and weight. Examples of area A (frying) production flow to area B (Cooling) has a conversion value of $16,512 \mathrm{~kg}$ meaning the ability of area A (Fryer) is able to move fried onion products to area B (cooling) as much as the conversion value.

\subsubsection{Creation of initial layout production travel tables}

Here is the initial layout production travel table:

Table 3. Initial layout production travel table

\begin{tabular}{|c|c|c|c|c|c|}
\hline \multirow{2}{*}{ To } & \multicolumn{4}{|c|}{ From } & \multirow{2}{*}{ Total } \\
\cline { 2 - 5 } & A & B & D & C & \\
\hline A & - & - & - & - & $\mathbf{0}$ \\
\hline B & 16512 & - & 13752 & - & $\mathbf{3 0 2 6 4}$ \\
\hline D & 6912 & 13824 & - & - & $\mathbf{2 0 7 3 6}$ \\
\hline C & - & 14898 & 2865 & - & $\mathbf{1 7 7 6 3}$ \\
\hline Total & $\mathbf{2 3 4 2 4}$ & $\mathbf{2 8 7 2 2}$ & $\mathbf{1 6 6 1 7}$ & $\mathbf{0}$ & $\mathbf{6 8 7 6 3}$ \\
\hline
\end{tabular}

From the table 3, is carried out forward and backward analysis as follows:

- Forward (Flow Tracking)

$=16512+14898+6912+13824+2865$

$=55011$

55011

$=\frac{55011}{68763} \times 100=80 \%$

- Backward (Back Tracking):

$=\frac{13752}{68763} \times 100=20 \%$

From the results of forward and backward analysis that has been done, they get the results of each percentage. 
Where the forward percentage results by $80 \%$ and backward by $20 \%$ for the initial layout. The results can be said to have been good because it has $>75 \%$. However, it is necessary to do a recalculation to validate that the layout is good.

\subsection{Proposed Layout Analysis}

In the analysis of the proposed layout utilizing a small empty area, where the empty area is located between area $\mathrm{A}$ and Area $\mathrm{C}$, so that it is still in one production line and does not experience the transfer of products that are far and also rotate, and the empty area will be coded "E" and used as a cooling area. The data is as follows:

Table 4. Data on production flow, distance, and weight of proposed layout analysis

\begin{tabular}{|c|c|c|c|}
\hline From the area & To the area & $\begin{array}{c}\text { Distance } \\
\text { (meter) }\end{array}$ & $\begin{array}{c}\text { Weight } \\
\text { (Kg) }\end{array}$ \\
\hline A (frying pan) & E (cooling) & 32 & 192 \\
\hline A (frying pan) & $\begin{array}{c}\text { D (area of } \\
\text { separation of } \\
\text { skin and flesh) }\end{array}$ & 36 & 192 \\
\hline $\begin{array}{c}\text { D (area of } \\
\text { separation of } \\
\text { skin and flesh) }\end{array}$ & E (cooling) & 19 & 191 \\
\hline E (cooling) & $\begin{array}{c}\text { D (area of } \\
\text { separation of } \\
\text { skin and flesh) }\end{array}$ & 19 & 192 \\
\hline $\begin{array}{c}\text { E (cooling) } \\
\text { with other } \\
\text { products) }\end{array}$ & 15 & 191 \\
\hline $\begin{array}{c}\text { D (area of } \\
\text { separation of } \\
\text { skin and flesh) }\end{array}$ & $\begin{array}{c}\text { C (mix area } \\
\text { with other } \\
\text { products) }\end{array}$ & 16 & 191 \\
\hline
\end{tabular}

From table 4, it can be explained that there is a significant change in distance between each area. Examples of mileage changing are quite significant due to the change in the area that was originally area "B" changed to area "E". The initial distance is 72 meters and after any change can be reached with only 19 meters and is within 1 complex area.

\subsubsection{Conversion support data and proposel layout travel data}

Here's a table of supporting data conversion data and proposed layout travel data:

Table 5. Proposed layout conversion values

\begin{tabular}{|c|c|c|c|c|}
\hline Product & Flow & $\begin{array}{c}\text { distance } \\
\text { (Meter) }\end{array}$ & $\begin{array}{c}\text { Weight } \\
\text { (Kg) }\end{array}$ & $\begin{array}{c}\text { Conversion } \\
\text { Value }\end{array}$ \\
\hline \multirow{4}{*}{$\begin{array}{c}\text { Fried } \\
\text { Onion }\end{array}$} & $\mathrm{A}->\mathrm{E}$ & 32 & 192 & 6144 \\
\cline { 2 - 5 } & $\mathrm{A}->\mathrm{D}$ & 36 & 192 & 6912 \\
\cline { 2 - 5 } & $\mathrm{D}->\mathrm{E}$ & 19 & 191 & 3629 \\
\cline { 2 - 5 } & $\mathrm{E}->\mathrm{D}$ & 19 & 192 & 3648 \\
\cline { 2 - 5 } & $\mathrm{E}->\mathrm{C}$ & 15 & 191 & 2865 \\
\cline { 2 - 5 } & $\mathrm{D}->\mathrm{C}$ & 16 & 191 & 3056 \\
\hline
\end{tabular}

From table 5, it is explained that the conversion value changes where there is a decrease. Examples of area $\mathrm{A}$ (frying) production flow to area E (Cooling) has a conversion value of $6144 \mathrm{~kg}$ meaning the ability of area A (Fryer) is able to move fried onion products to area $\mathrm{E}$ (cooling) of the conversion value.

\subsubsection{Creation of proposed layout production travel tables}

Here is the proposed layout production travel table:

Table 6. Proposed layout production travel table

\begin{tabular}{|c|c|c|c|c|c|}
\hline \multirow{2}{*}{ To } & \multicolumn{4}{|c|}{ From } & \multirow{2}{*}{ Total } \\
\hline & A & B & D & $\mathrm{C}$ & \\
\hline A & - & - & - & - & 0 \\
\hline E & 6144 & - & 3629 & - & 9773 \\
\hline D & 6912 & 3648 & - & - & 5921 \\
\hline C & - & 2865 & 3056 & - & 10560 \\
\hline Total & 13.056 & 6513 & 6685 & - & 26254 \\
\hline
\end{tabular}

From the table 6, is carried out forward and backward analysis as follows:

- Forward (Flow Tracking)

$=6144+6912+3648+2865+3056$

$=22625$

22625

$=\frac{2625}{26254} \times 100=86.18 \%$

- Backward (Back Tracking)

$=\frac{3629}{26254} \times 100=13.82 \%$

From the results of forward analysis and backward layout of the proposal that has been done, there are percentage results respectively, where the forward percentage result is $86.18 \%$ and backward by $13.82 \%$. The results of the proposed layout have a higher forward value than the initial layout, it can be said that the proposed layout provides better efficiency and is able to reduce the occurrence of inefficient flow. The proposed layout form is:

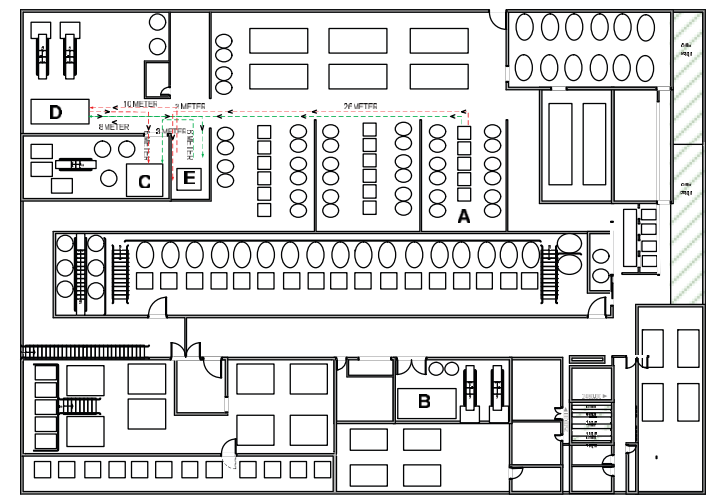

Fig 2. Layout of proposed fried onion production flow 


\section{Conclusion}

From the processing results obtained that the proposed layout is better than the initial layout with a higher flow efficiency value of $86.18 \%$. The proposed layout utilizes vacant land, so that the production flow does not repeat and does not rotate far, so that the distance between the areas is getting closer. Inefficient production flow is decreased, this is in accordance with the goal of the From to Chart method which is to minimize inefficient flow. In future studies can compare with the addition of cost components and can also compare with other methods.

\section{References}

[1] S. Masoud, B. D. B. Chowdhury, Y. J. Son, C. Kubota, and R. Tronstad, "Simulation based optimization of resource allocation and facility layout for vegetable grafting operations," Comput. Electron. Agric., vol. 163, no. May, p. 104845, (2019), doi: 10.1016/j.compag.2019.05.054.

[2] S. Barnwal and P. Dharmadhikari, "Optimization of Plant Layout Using SLP Method," Int. J. Innov. Res. Sci. Eng. Technol., vol. 5, no. 3, pp. 3008-3015, (2016), doi: 10.15680/IJIRSET.2016.0503046.

[3] B. Suhardi, E. Juwita, and R. D. Astuti, "Facility layout improvement in sewing department with Systematic Layout planning and ergonomics approach," Cogent Eng., vol. 6, no. 1, (2019,) doi: 10.1080/23311916.2019.1597412.

[4] I. F. Febriandini and Yuniaristanto, "Re-design Facility Layout using Systematic Layout Planning Method: A Case Study: ro Cosmeceutical Sdn. Bhd.," IOP Conf. Ser. Mater. Sci. Eng., vol. 495, no. 1, (2019), doi: 10.1088/1757-899X/495/1/012027.

[5] A. T. Haryanto, M. Hisjam, and W. K. Yew, "Redesign of Facilities Layout Using Systematic Layout Planning (SLP) on Manufacturing Company: A Case Study," IOP Conf. Ser. Mater. Sci. Eng., vol. 1096, no. 1, p. 012026, (2021), doi: 10.1088/1757899x/1096/1/012026.

[6] J. Haekal, D. Eko, and A. Prasetio, "Planning Of Production Facilities Layouts In Home Industry With The Systematic Layout Planning Method," Int. J. Innov. Sci. Eng. Technol., vol. 7, no. 10, pp. 147-153, (2020).

[7] M. A. Naim, E. Rimawan, . M., and A. Putri, "Relayout Production Facility of PC. Spun Pile Using Systematic Layout Planning in ABC Factory," Int. J. Innov. Sci. Res. Technol., vol. 5, no. 8, pp. 1620-1629, (2020), doi: 10.38124/ijisrt20aug614.

[8] L. Kaifan, Z. Ailian, and W. Kefeng, "Layout Design of Chang-Zhu-Tan Tobacco Logistics Park Based on SLP Method," J. Phys. Conf. Ser., vol. 1972, no. 1, p. 012085, (2021), doi: 10.1088/1742-6596/1972/1/012085.

[9] C. R. Yusuf and N. N. Triana, "Layout Planning
Floor Production Bread Factory Using Systematic Layout Planning Methods," vol. 1, no. 1, pp. 62-69, (2020).

[10] R. Prasetyani, A. Siti, and G. A. Timang, "Design of Facility Location for new model of Medical Pharmaceutical Refrigerator Production Area on PT. XYZ," IOP Conf. Ser. Mater. Sci. Eng., vol. 847, no. 1, (2020), doi: 10.1088/1757-899X/847/1/01(2009).

[11] S. A. Ali Naqvi, M. Fahad, M. Atir, M. Zubair, and M. M. Shehzad, "Productivity improvement of a manufacturing facility using systematic layout planning," Cogent Eng., vol. 3, no. 1, (2016), doi: 10.1080/23311916.2016.1207296.

[12] N. T. Putri and L. S. Dona, "Application of lean manufacturing concept for redesigning facilities layout in Indonesian home-food industry: A case study," TQM J., vol. 31, no. 5, pp. 815830, (2019), doi: 10.1108/TQM-02-2019-0033.

[13] S. Halim, C. Alianto, and T. Octavia, "Facility Layout Design Using Business Intelligence Approach: A Case Study in an Amusement Arcade," Int. J. Ind. Res. Appl. Eng., vol. 3, no. 2, pp. 1711-1721, (2019), doi: 10.9744/jirae.3.2.86-93.

[14] A. Shaker Abualsaud, A. Ahmed Alhosani, A. Youssef Mohamad, F. Nasser Al Eid, and I. Alsyouf, "Using six sigma DMAIC methodology to develop a facility layout for a new production line," 2019 8th Int. Conf. Model. Simul. Appl. Optim. ICMSAO 2019, pp. 1-5, (2019), doi: 10.1109/ICMSAO.2019.8880335.

[15] I. Siregar, U. Tarigan, and T. H. Nasution, "Layout design in order to improve efficiency in manufacturing," IOP Conf. Ser. Mater. Sci. Eng., vol. 309, no. 1, 2018, doi: 10.1088/1757899X/309/1/012001.

[16] D. Suhardini, W. Septiani, and S. Fauziah, "Design and Simulation Plant Layout Using Systematic Layout Planning," IOP Conf. Ser. Mater. Sci. Eng., vol. 277, no. 1, (2017), doi: 10.1088/1757-899X/277/1/012051.

[17] G. J. L. Micheli, A. Rampoldi, and F. Baccanti, "A revised systematic layout planning to fit disabled workers contexts," Sustain., vol. 13, no. 12, (2021), doi: 10.3390/su13126850.

[18] Y. Liu and J. Xu, "Optimization on production line layout of automobile body shop," 14th Int. Conf. Serv. Syst. Serv. Manag. ICSSSM 2017 Proc., pp. 1-6, (2017), doi: 10.1109/ICSSSM.2017.7996213.

[19] G. Kovács and S. Kot, "Facility layout redesign for efficiency improvement and cost reduction," J. Appl. Math. Comput. Mech., vol. 16, no. 1, pp. 63-74, (2017), doi: 10.17512/jamcm.2017.1.06.

[20] J. M. R. Joko Susetyo, Risma Adelia Simanjutak, "PENDEKATAN GROUP TECHNOLOGY DAN ALGORITMA BLOCPLAN UNTUK MEMINIMASI ONGKOS MATERIAL HANDLING Joko Susetyo , Risma Adelina Simanjuntak , João Magno Ramos," J. Teknol., vol. 3, no. Juni, pp. 
75-83, (2010).

[21] K. Bintang Bagaskara, L. Gozali, and L. Widodo, "Redesign layout planning of raw material area and production area using systematic layout planning (SLP) methods (case study of CV oto boga jaya)," IOP Conf. Ser. Mater. Sci. Eng., vol. 852, no. 1, (2020), doi: 10.1088/1757-899X/852/1/012122.

[22] C. Chen, D. Tran Huy, L. K. Tiong, I. M. Chen, and Y. Cai, "Optimal facility layout planning for AGV-based modular prefabricated manufacturing system," Autom. Constr., vol. 98, no. May, pp. 310-321, (2019), doi: 10.1016/j.autcon.2018.08.008.

[23] B. Suhardi, L. Elvira, and R. D. Astuti, "FACILITY LAYOUT REDESIGN USING SYSTEMATIC LAYOUT PLANNING," vol. 15, no. 1, pp. 57-68, (2021).

[24] S. Pramija, "Redesign of Facility Layout at Pelangi Advertising Printing Using the SLP Method," vol. 65, no. 2, pp. 77-81, (2021).

[25] A. M. Golmohammadi, H. Bani-Asadi, H. Esmaeeli, H. Hadian, and F. Bagheri, "Facility layout for cellular manufacturing system under dynamic conditions," Decis. Sci. Lett., vol. 5, no. 3, pp. 407-416, (2016), doi: 10.5267/j.ds1.2016.2.001.

[26] S. B. Naik and S. Kallurkar, "a Literature Review on Efficient Plant Layout Design," Int. J. Ind. Eng. Res. Dev., vol. 7, no. 2, (2016), doi: 10.34218/ijierd.7.2.2016.005. 